\title{
Hallazgos radiológicos en la isquemia mesentérica
}

\author{
Radiological findings in mesenteric ischemic
}

\section{CASE REPORT}

A 78-year-old man suffering from type 2 diabetes, hypertension, and severe obesity, presented to the Emergency Department with acute and generalized abdominal pain and distension, nausea and vomiting over 12 hours. Physical examination showed pale skin, diaphoresis, body temperature of $38.1^{\circ} \mathrm{C}$, pulse rate of 92 beats/min, blood pressure of $81 / 58 \mathrm{mmHg}$, respiratory rate of 26 breaths/min and Glasgow Coma Score 14 (due to confusion); enlarged and extremely tender abdomen, as well as decreased bowel sounds. Blood work presented leucocytosis, $\mathrm{C}$ reactive protein elevation and hyperlacticaemia. Hence signs of probably abdominal sepsis, blood cultures were promptly collected, intravenous broad-spectrum antibiotics were started (ceftriaxone and metronidazole) and initiated fluid challenge. It was performed an emergent abdominal-pelvic contrast-enhanced computed tomography scan which revealed portal venous gas (PVG) (Figure 1-A), pneumatosis intestinalis (PI) (Figure 1-B) and large gastroparesis (Figure 1-C). With careful further appreciation, it was found an image compatible with a clot at the superior mesenteric artery (Figure 1-D).

The patient was then rushed to the Operating Room for an exploratory laparotomy, with large intestinal resection and peritoneal lavage. Unfortunately, this case had a fatal disclosure few hours after the surgery.

Though rare, aeroportia and PI are relevant radiological findings, strongly associated with intestinal ischemia ${ }^{[1]}$. However, each of these findings alone are not pathognomonic for this diagnose and they might relate with non-ischemic causes, such as inflammatory bowel disease, intestinal occlusion, and infections ${ }^{[2,3]}$.

As such, diagnosing mesenteric ischemia can be challenging, specially in patients with multiple comorbidities. Even though CT scan allows identification of early signs, such as aeroportia and PI, the outcome is often poor (about 75\% mortality rate). Do so, early diagnosis and intervention are crucial to a better outcome ${ }^{[2]}$.

\section{CONFLICTO DE INTERESES}

No existen conflictos de interés por parte de los autores de este trabajo.

\section{FINANCIACIÓN}

No ha existido financiación externa de ningún tipo para llevar a cabo el presente trabajo.

\section{ASPECTOS ÉTICOS}

Se ha solicitado consentimiento informado explícito a los pacientes participantes en el presente trabajo.
Figure 1. Abdominal-pelvic contrast-enhanced CT scan showing portal venous gas (A), pneumatosis intestinalis $(\mathrm{B})$, gastroparesis $(\mathrm{C})$ and superior mesenteric artery clot $(\mathrm{D})$
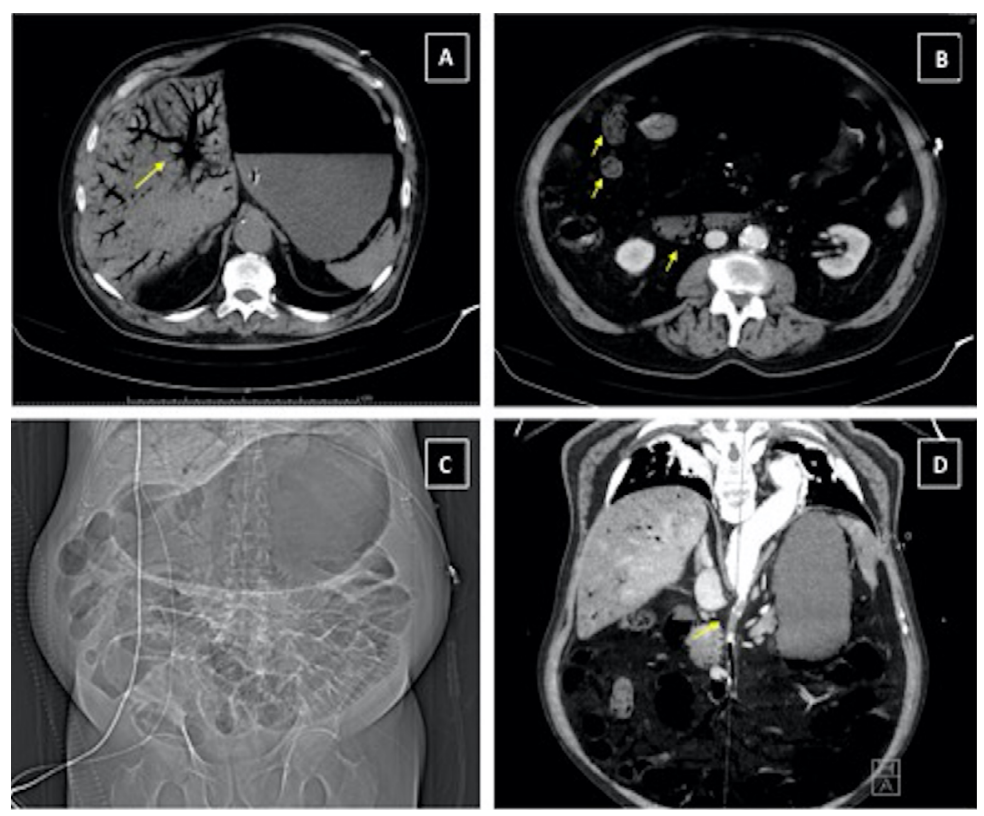

\section{REFERENCES}

1. Wiesner W, Mortelé KJ, Glickman JN, et al. Pneumatosis intestinalis and portomesenteric venous gas in intestinal ischemia: correlation of CT findings with severity of ischemia and clinical outcome. AJR Am J Roentgenol 2001;177:1319-23

2. Shung-Wei Liu and Tai-Yu Huang. Portal venous gas and pneumatosis intestinalis. CMAJ February 19, 2013185 (3) E175

3. Kinoshita H, Shinozaki M, Tanimura H, Umemoto Y, Sakaguchi S, Takifuji K, et al. Clinical features and management of hepatic portal venous gas: four case reports and cumulative review of the literature. Arch. Surg. 2001;136:1410-1414

Palabras clave: isquemia mesentérica, aeroportia, neumatosis intestinal.

Keywords: mesenteric ischemic, aeroportia, intestinal pneumatosis.

\section{Teresa Salero, Sergio Pina}

Centro Hospitalar Universitario do Algarve

Correspondencia: teresa_salero@hotmail.com

Cómo citar este artículo: Salero T, Pina S

Hallazgos radiológicos em la isquemia mesentérica. Galicia Clin 2021; 82-4: 236

Recibido: 27/9/20; Aceptado: 1/2/21 // https://doi.org/10.22546/63/2377 